INFLAMMATORY BOWEL DISEASE

\title{
Environmental risk factors in paediatric inflammatory bowel diseases: a population based case control study
}

\author{
S Baron, D Turck, C Leplat, V Merle, C Gower-Rousseau, R Marti, T Yzet, E Lerebours, J-L Dupas, \\ S Debeugny, J-L Salomez, A Cortot, J-F Colombel
}

Gut 2005;54:357-363. doi: 10.1136/gut.2004.054353

See end of article for authors' affiliations

.....................

Correspondence to: Professor J-F Colombel, Department of HepatoGastroenterology and Registre EPIMAD, Hopital Claude Huriez, $\mathrm{CH}$ et $\mathrm{U}$ de Lille, 59037 Lille Cedex, France; jfcolombel@ chru-lille.fr

Revised version received 9 September 2004 Accepted for publication 12 September 2004

\begin{abstract}
Background: Environmental exposures in early life have been implicated in the aetiology of inflammatory bowel disease.

Objective: To examine environmental risk factors prior to the development of inflammatory bowel disease in a paediatric population based case control study.

Methods: A total of 222 incident cases of Crohn's disease and 60 incident cases of ulcerative colitis occurring before 17 years of age between January 1988 and December 1997 were matched with one control subject by sex, age, and geographical location. We recorded 140 study variables in a questionnaire that covered familial history of inflammatory bowel disease, events during the perinatal period, infant and child diet, vaccinations and childhood diseases, household amenities, and the family's socioeconomic status.

Results: In a multivariate model, familial history of inflammatory bowel disease (odds ratio (OR) 4.3 (95\% confidence interval 2.3-8)), breast feeding (OR 2.1 (1.3-3.4)), bacille Calmette-Guerin vaccination (OR $3.6(1.1-11.9))$, and history of eczema (OR 2.1 (1-4.5)) were significant risk factors for Crohn's disease whereas regular drinking of tap water was a protective factor (OR $0.56(0.3-1))$. Familial history of inflammatory bowel disease (OR 12.5 (2.2-71.4)), disease during pregnancy (OR 8.9 (1.5-52)), and bedroom sharing (OR 7.1 (1.9-27.4)) were risk factors for ulcerative colitis whereas appendicectomy was a protective factor (OR $0.06(0.01-0.36)$ ).

Conclusions: While family history and appendicectomy are known risk factors, changes in risk based on domestic promiscuity, certain vaccinations, and dietary factors may provide new aetiological clues.
\end{abstract}

$\mathrm{T}$ he pathophysiology of inflammatory bowel diseases (IBD) is still unknown but epidemiological studies show clear evidence of genetic susceptibility. ${ }^{12}$ This evidence has been supplemented by molecular genetic data from genome wide linkage scans and candidate gene studies. Identification of the first IBD susceptibility gene, NOD2/ CARD15, has been a major breakthrough in genetic research and may provide a key step towards unravelling the aetiology of the disease. However, fundamental features of IBD such as the significant geographical variation in disease incidence and rapid rise in the incidence of Crohn's disease (CD) over the past century cannot be accounted for by genetic predisposition alone. ${ }^{34}$

There is accumulating evidence that events early in life may have long term effects on health and disease. Several epidemiological studies have suggested a role for perinatal or childhood events in the aetiology of IBD. ${ }^{3}{ }^{4}$ Both non-specific exposures and specific exposures have been studied. Nonspecific exposures include gastroenteritis and other nonspecific infections. Specific exposures include measles virus infection and vaccines, appendicectomy, and passive smoking. As for autoimmune diseases, a consistent finding in early observational studies for both CD and ulcerative colitis (UC) was the association between high socioeconomic status and an increased risk. ${ }^{5-7}$ An attractive theory to explain this association is that it may result from a decrease in the prevalence of early childhood infections. ${ }^{8}$ However, there are no solid data indicating either a positive or negative role of hygiene in the development of IBD.

A registry of IBD (EPIMAD) has been running in Northern France since $1988 .{ }^{9}{ }^{10}$ It provides access to a large population based cohort of patients with IBD which is suitable for environmental studies. Here we report the results of a case control study examining environmental risk factors prior to the development of IBD in the subset of patients who were less than 17 years old at diagnosis.

\section{MATERIAL AND METHODS} Study design

This was a population based matched case control study. Cases were all patients from the EPIMAD registry who had a diagnosis of either CD or UC between January 1988 and December 1997 and were less than 17 years old at the time of IBD diagnosis. Controls were randomly selected from telephone number lists (random digit dialling) and matched 1:1 to each case by age ( \pm 2 years), sex, and living area (region).

\section{Case identification and diagnostic criteria}

The study area was the northern part of France which has 5790526 inhabitants (1999 national population census) and is divided into four regions: Nord, Pas-de-Calais, Somme, and Seine-Maritime. The paediatric population under 17 years of age is as follows: Nord $=593$ 837; Pas de Calais $=332228$ (these 2 regions constitute and will be referred as the NordPas de Calais region); Somme $=115$ 969; Seine-Maritime $=$ 270107 (total 1312 141). The methodology of the EPIMAD registry has previously been described in details. ${ }^{90}$ Briefly, interviewer practitioners collected data on all patients diagnosed between 1 January 1988 and 31 December 1997 from all gastroenterologists (including paediatric gastroenterologists) in the whole area. Only patients who had been residents in the defined study areas at the time of

Abbreviations: IBD, inflammatory bowel disease; $C D$, Crohn's disease; UC, ulcerative colitis; BCG, bacille Calmette-Guerin; MMR, measlesmumps-rubella; $O R$, odds ratio 
Table 1 Sociodemographic characteristics of the children and parents

\begin{tabular}{|c|c|c|c|c|c|c|}
\hline & \multicolumn{3}{|c|}{ Crohn's disease } & \multicolumn{3}{|c|}{ Ulcerative colitis } \\
\hline & $\begin{array}{l}\text { Cases (\%) } \\
(n=222)\end{array}$ & $\begin{array}{l}\text { Controls (\%) } \\
(n=222)\end{array}$ & p Value & $\begin{array}{l}\text { Cases (\%) } \\
(n=60)\end{array}$ & $\begin{array}{l}\text { Controls }(\%) \\
(n=60)\end{array}$ & p Value \\
\hline \multicolumn{7}{|l|}{ Sex } \\
\hline Male & $120(54)$ & $120(54)$ & & $23(38)$ & $23(38)$ & \\
\hline Female & $102(46)$ & $102(46)$ & & 37 (62) & 37 (62) & \\
\hline Median age at diagnosis (y) & 13.5 & - & & 14.1 & - & \\
\hline \multicolumn{7}{|l|}{ Living area } \\
\hline Nord-Pas de Calais & $152(68)$ & $152(68)$ & & 46 (77) & 46 (77) & \\
\hline Somme & $34(15)$ & 34 (15) & & $4(6)$ & $4(6)$ & \\
\hline Seine Maritime & $36(17)$ & $36(17)$ & & $10(17)$ & 10 (17) & \\
\hline Child's educational level & & & 0.58 & & & 0.16 \\
\hline$\leqslant 5 y$ & $12(5)$ & $10(5)$ & & $0(0)$ & $3(5)$ & \\
\hline $5-11 y$ & $86(39)$ & $97(44)$ & & $28(47)$ & $23(38)$ & \\
\hline $12 y$ & $49(22)$ & $41(18)$ & & $10(17)$ & $16(27)$ & \\
\hline$>12 y$ & $75(34)$ & 74 (33) & & $22(36)$ & $18(30)$ & \\
\hline \multicolumn{7}{|l|}{ Siblings } \\
\hline No sibling & $17(8)$ & 33 (15) & 0.02 & $7(12)$ & $7(12)$ & 1 \\
\hline Older siblings & 137 & 114 & 0.02 & 40 & 29 & 0.05 \\
\hline Younger siblings & 130 & 121 & 0.39 & 37 & 28 & 0.14 \\
\hline Father's educational level & & & 0.44 & & & \\
\hline$\leqslant 5 y$ & $37(17)$ & $28(13)$ & & $7(12)$ & $1(2)$ & \\
\hline $5-11 y$ & $118(53)$ & $115(52)$ & & $35(58)$ & $31(52)$ & \\
\hline $12 y$ & $28(13)$ & 37 (17) & & $7(12)$ & $12(20)$ & \\
\hline$>12 y$ & $35(17)$ & $38(18)$ & & $10(18)$ & $15(25)$ & \\
\hline Mother's educational level & & & 0.55 & & & 0.24 \\
\hline$\leqslant 5 y$ & $34(15)$ & $30(14)$ & & $5(8)$ & $4(7)$ & \\
\hline $5-11$ y & $123(55)$ & $116(52)$ & & $41(68)$ & $32(53)$ & \\
\hline $12 y$ & 30 (13) & 43 (19) & & $8(13)$ & 11 (18) & \\
\hline$>12 y$ & $35(17)$ & $33(15)$ & & $6(11)$ & $13(22)$ & \\
\hline
\end{tabular}

diagnosis of their disease were included. A final diagnosis of CD or UC was made by two expert gastroenterologists and recorded as definite, probable, or possible, following criteria previously published. ${ }^{9}$ For the purpose of this study, only patients with definite or probable CD or UC were considered.

\section{Questionnaires}

Trained investigators personally interviewed both the study subject and his (her) mother at home. Investigators and participants were blind to the study hypotheses. Questions covered the period from birth to the date of diagnosis or corresponding period for controls (from birth to age at diagnosis of the matched case). The "carnet de santé" (paediatric health booklet that is mandatory in France for infants, children, and adolescents, with information on pregnancy, delivery, child's growth, vaccination, childhood infections, etc) was required to validate questions about the child's health. A questionnaire was devised comprising 140 questions relating to six different areas: (i) family history of IBD; (ii) perinatal period (disease during pregnancy, gestational age at birth, birth weight and height, and infection and hospitalisation during the first month of life); (iii) infant and child diet (including questions on passive and active smoking); (iv) childhood infections (measles, mumps, rubella, chicken pox, whooping cough, croup, scarlet fever, hepatitis), other childhood diseases (asthma, eczema), surgery (tonsillectomy, adenoidectomy, appendicectomy, and others) and vaccines (measles- mumps-rubella (MMR) vaccine, bacille Calmette-Guerin vaccine (BCG), diphtheria, tetanus, poliomyelitis, pertussis vaccine, and others). In France, smallpox vaccination within the first two years of life was mandatory until 1978 and BCG within the first six years of life until the present. More than one dose of BCG can be administered in the case of a negative skin tuberculin test; (v) home amenities (presence of bathroom, hot water, mains drainage, septic tank, etc), water consumption (tap water, bottle water, water from well), type and size of housing (flat, house, other), and presence of animals (pets, others animals). Area was registered as urban or rural according to the INSEE (French national statistics institute) classification of French communities. For each house, entry date and leaving date were registered allowing evaluation of the duration of exposure to each risk factor. If there were major changes in housing (septic tank replaced by mains drainage, for example), it was considered as two different housings; (vi) parents' and child's socioeconomic status. Total duration of the interview was approximately two hours. A copy of the interview form is available on request from one of the authors (CGR).

\section{Data management}

Each investigator coded most of the answers for computer analysis using standard rules. Questionnaires were sent to the Department of Epidemiology and Public Health, Lille University Hospital, and the remaining answers were coded and incoherences checked. Particular attention was paid to the date of each event in order to consider only those occurring before the onset of disease for cases and in the corresponding time period for controls.

Parents of affected children or controls and children who were more than 18 years at the time of inquiry gave informed written consent. Approval for the survey was obtained from local and national ethics committees for human studies.

\section{Statistical analysis}

Separate analysis was performed for patients with CD and their matched controls, and for patients with UC and their matched controls. Characteristics of the populations were described using median values (with 25th and 75th percentiles) for quantitative variables and frequencies for qualitative variables.

Univariate associations between potential risk factors and CD or UC were compared with tests for matched series: for qualitative variables the McNemar $\chi^{2}$ test was used and for quantitative variables the Wilcoxon rank sum test. A p value of $<0.05$ was considered to denote a statistically significant difference. In multivariate analysis, based on conditional 
Table 2 Association of Crohn's disease (CD) with childhood factors: univariate analysis

\begin{tabular}{|c|c|c|c|}
\hline & $C D$ & OR & $95 \% \mathrm{Cl}$ \\
\hline Familial history of IBD & & 4.6 & $2.6-8.3$ \\
\hline Pairs with exposed cases/non-exposed controls & 65 & & \\
\hline Pairs with non-exposed cases/exposed controls & 14 & & \\
\hline Concordant pairs & 141 & & \\
\hline Breast feeding & & 1.6 & $1.1-2.4$ \\
\hline Pairs with exposed cases/non-exposed controls & 66 & & \\
\hline Pairs with non-exposed cases/exposed controls & 41 & & \\
\hline Concordant pairs & 115 & & \\
\hline Eczema & & 2.9 & $1.5-5.6$ \\
\hline Pairs with exposed cases/non-exposed controls & 35 & & \\
\hline Pairs with non-exposed cases/exposed controls & 12 & & \\
\hline Concordant pairs & 175 & & \\
\hline MMR vaccination & & 0.5 & $0.35-0.9$ \\
\hline Pairs with exposed cases/non-exposed controls & 16 & & \\
\hline Pairs with non-exposed cases/exposed controls & 32 & & \\
\hline Concordant pairs & 184 & & \\
\hline Smallpox vaccination & & 2.1 & $1-4.3$ \\
\hline Pairs with exposed cases/non-exposed controls & 23 & & \\
\hline Pairs with non-exposed cases/exposed controls & 11 & & \\
\hline Concordant pairs & 188 & & \\
\hline BCG vaccination & & 2.8 & $1.1-7.2$ \\
\hline Pairs with exposed cases/non-exposed controls & 17 & & \\
\hline Pairs with non-exposed cases/exposed controls & 6 & & \\
\hline Concordant pairs & 199 & & \\
\hline Poliomyelitis vaccination & & 2.6 & $1.1-6.2$ \\
\hline Pairs with exposed cases/non-exposed controls & 18 & & \\
\hline Pairs with non-exposed cases/exposed controls & 7 & & \\
\hline Concordant pairs & 197 & & \\
\hline Tap water consumption & & 0.5 & $0.3-0.8$ \\
\hline Pairs with exposed cases/non-exposed controls & 25 & & \\
\hline Pairs with non-exposed cases/exposed controls & 49 & & \\
\hline Concordant pairs & 148 & & \\
\hline Bedroom sharing & & 1.6 & $1-2.4$ \\
\hline Pairs with exposed cases/non-exposed controls & 58 & & \\
\hline Pairs with non-exposed cases/exposed controls & 27 & & \\
\hline Concordant pairs & 148 & & \\
\hline
\end{tabular}

logistic regression, variables with a p value $<0.2$ in the univariate analysis were proposed for entry into the model. Potential confounding factors were proposed in the model. We used a forward procedure in which we set $p=0.1$ for the independent variables to enter into the model. In most paediatric studies, mother's educational level is the most relevant variable associated with child's health and child's use of health services. Therefore, in multivariate analysis, results were adjusted on mother's educational level and father's educational level, irrespective of statistical significance in the univariate analysis. Adequacy of the models to the data was tested using the Hosmer and Lesmeshow test. For multivariate analysis, odds ratios (OR) and confidence intervals (CI) were estimated by maximising the conditional likelihood function. Univariate and multivariate analyses were performed using SAS V8 software (SAS Institute, Cary, North Carolina, USA).

\section{RESULTS}

\section{Cohort description (table 1)}

All IBD cases but two and all selected controls agreed to participate in the study. No child had died since 1988 and all natural mothers were available for interview. Two children who moved from the area were lost to follow up. Four pairs were not maintained in the study because of inappropriate matching. Among the 282 remaining subjects, 222 had CD and 60 had UC. Median age at diagnosis was 13.5 years for CD (interquartile range $11-15$ ) and 14 years for UC (11-15). There was a majority of males in the CD group (54\%) and a majority of females in the UC group (61.6\%); $70.3 \%$ of children were from the Nord-Pas de Calais region, 13.4\% from Somme, and 16.3\% from Seine Maritime, reflecting the respective populations of each region. A total of 3525 phone calls were made in order to recruit 282 controls (8\%): 905 people $(26 \%)$ answered, among whom 554 did not meet the inclusion criteria. Among the 351 remaining who met the inclusion criteria, 69 did not want to participate. Educational level was similar in cases and controls $(p=0.9)$. There was no significant difference between cases and controls regarding socioeconomic status (mother and father) or parents' educational level. The paediatric health booklet was available for $96 \%$ of patients and $93 \%$ of controls. Patients with CD had more siblings than controls $(\mathrm{p}=0.02)$ and patients with $\mathrm{CD}$ and UC had more older siblings than controls $(p=0.02$ and $\mathrm{p}=0.05$, respectively).

\section{Crohn's disease}

Due to the number of questions, only positive findings are reported and what we consider the most important results.

\section{Univariate analysis (table 2) \\ Family IBD history}

A family history of IBD was the strongest risk factor for CD in univariate analysis with an OR of 4.6 (95\% CI 2.6-8.3; $\mathrm{p}<0.001)$.

\section{Perinatal period}

No specific factor was associated with $C D$ in univariate analysis. None of the mothers reported measles during pregnancy. Gestational age and anthropometric measurements at birth were similar in cases and controls.

\section{Infant and child diet}

Breast feeding, either partial or exclusive, was a risk factor for CD with an OR of $1.6(1.1-2.4 ; p=0.01)$ and of $1.6(1.1-2.5$; 
Table 3 Association of Crohn's disease with childhood factors: multivariate analysis

\begin{tabular}{lllc}
\hline & OR & Cl & p Value \\
\hline Family IBD history & 4.3 & $2.3-8$ & $<0.001$ \\
Breast feeding & 2.1 & $1.3-3.4$ & 0.003 \\
Eczema & 2.1 & $1-4.5$ & 0.04 \\
BCG vaccination & 3.6 & $1.1-11.9$ & 0.03 \\
Drinking tap water & 0.6 & $0.3-1$ & 0.05 \\
\hline
\end{tabular}

Results are expressed as odds ratios (OR) with $95 \%$ confidence interval (CI).

IBD, inflammatory bowel disease; BCG, bacille Calmette-Guerin

$p=0.01$ ), respectively. CD children were breast fed exclusively and non-exclusively on average two weeks more than controls but the difference was not significant ( 10 weeks $v$ eight weeks, and eight weeks $v$ six weeks, respectively) $(p=0.08)$. There was no significant difference in the age of introduction of flour, meat, and vegetables. There was no difference between cases and controls for passive smoking due to parents or caregivers (OR $0.84(0.55-1.3)$ ).

\section{Childhood diseases, vaccinations}

There were no significant differences between cases and controls regarding measles, (OR 1.1 (0.7-1.6)), mumps, rubella, or other infections. Eczema before the age of two years was more frequent in CD than in controls with an OR of 2.9 (1.5-5.6; $\mathrm{p}=0.001)$. Appendicectomy was a risk factor for CD (OR 1.7). Surgical and pathological reports of appendicectomies were then reviewed when appendicectomy was performed within one year before the onset of symptoms ( 13 children). Appendicectomy revealed CD in 9/13 cases and was thus considered incidental. After excluding these cases the association did not remain significant. No difference was noted between CD and controls regarding other surgeries frequently performed during childhood such as adenoidectomy and tonsillectomy. CD children were exposed more often to smallpox vaccination (OR $2.1(1-4.3) ; \mathrm{p}=0.04)$, poliomyelitis vaccination (OR $2.6(1.1-6.2)$; $\mathrm{p}=0.03)$, and BCG vaccination (OR $2.8(1-4.3) ; \mathrm{p}=0.04)$. For $\mathrm{BCG}$, there was a dose effect: OR $2.6(1-6.5 ; p=0.05)$ for one shot versus no vaccination, and OR $3.65(1.4-9.7 ; p=0.01)$ for more than one shot versus no vaccination. $C D$ children were exposed less often to MMR vaccination ( OR $0.5(0.35-0.9)$; $\mathrm{p}=0.01)$.

\section{Home amenities}

More than $95 \%$ of children had permanent access to separate bathrooms and fixed hot water during their whole childhood. CD cases reported less tap water consumption than controls (OR 0.5 (0.3-0.8); $\mathrm{p}=0.006)$. CD children shared their bedroom with family members more often (OR 1.6 (1-2.4); $\mathrm{p}=0.02$ ).

\section{Multivariate analysis (table 3)}

In multivariate analysis, adjusted for mother's educational level, five variables remained significant: family history of IBD, breast feeding, history of eczema, and BCG vaccination were independent risk factors while drinking tap water was protective.

\section{Ulcerative colitis \\ Univariate analysis (table 4) \\ Family IBD history}

A family history of IBD was the strongest risk factor for UC in univariate analysis with an OR of $5(1.45-17.2 ; \mathrm{p}=0.005)$.

\section{Perinatal period}

Disease during pregnancy, including risk of premature delivery $(n=6)$, hormonal treatment $(n=2)$, hypertension $(\mathrm{n}=3)$, rubella vaccine $(\mathrm{n}=2)$, and other $(\mathrm{n}=4)$, were more frequent in mothers of UC patients (OR 4.67 (1.3-16.1); $\mathrm{p}=0.008)$. None of the mothers reported measles during pregnancy.

Table 4 Association of ulcerative colitis (UC) with childhood factors. Univariate analysis

\begin{tabular}{|c|c|c|c|}
\hline & UC & OR & $95 \% \mathrm{Cl}$ \\
\hline Familial history of IBD & & 5 & $1.45-17.2$ \\
\hline Pairs with exposed cases/non-exposed controls & 15 & & \\
\hline Pairs with non-exposed cases/exposed controls & 3 & & \\
\hline Concordant pairs & 42 & & \\
\hline Disease during pregnancy* & & 4.7 & $1.3-16.1$ \\
\hline Pairs with exposed cases/non-exposed controls & 14 & & \\
\hline Pairs with non-exposed cases/exposed controls & 3 & & \\
\hline Concordant pairs & 43 & & \\
\hline Sucrose supplemented milk & & 2.25 & $1-5.2$ \\
\hline Pairs with exposed cases/non-exposed controls & 18 & & \\
\hline Pairs with non-exposed cases/exposed controls & 8 & & \\
\hline Concordant pairs & 34 & & \\
\hline Appendicectomy & & 0.3 & $0.1-0.95$ \\
\hline Pairs with exposed cases/non-exposed controls & 3 & & \\
\hline Pairs with non-exposed cases/exposed controls & 11 & & \\
\hline Concordant pairs & 46 & & \\
\hline Smallpox vaccination & & 10 & $1.3-208$ \\
\hline Pairs with exposed cases/non-exposed controls & 10 & & \\
\hline Pairs with non-exposed cases/exposed controls & 1 & & \\
\hline Concordant pairs & 49 & & \\
\hline Poliomyelitis vaccination & & 7 & $1.1-151$ \\
\hline Pairs with exposed cases/non-exposed controls & 7 & & \\
\hline Pairs with non-exposed cases/exposed controls & 1 & & \\
\hline Concordant pairs & 52 & & \\
\hline Bedroom sharing & & 3.4 & $1.5-7.9$ \\
\hline Pairs with exposed cases/non-exposed controls & 24 & & \\
\hline Pairs with non-exposed cases/exposed controls & $\begin{array}{r}24 \\
7\end{array}$ & & \\
\hline Concordant pairs & 29 & & \\
\hline
\end{tabular}

Values are expressed as odds ratios (OR) with $95 \%$ confidence interval (CI).

*Disease during pregnancy: risk of premature delivery $(n=6)$; hormonal treatment during pregnancy $(n=2)$; hypertension $(n=3)$; rubella vaccine $(n=2)$; and other $(n=4)$. 
Table 5 Association of ulcerative colitis with childhood factors: multivariate analysis

\begin{tabular}{lcll}
\hline & OR & Cl & p Value \\
\hline Family IBD history & 12.5 & $2.2-71.4$ & 0.005 \\
Disease during pregnancy & 8.9 & $1.5-52$ & 0.02 \\
Bedroom sharing & 7.1 & $1.9-27.4$ & 0.004 \\
Appendicectomy & 0.06 & $0.01-0.36$ & 0.002
\end{tabular}

Values are expressed as odds ratios (OR) with $95 \%$ confidence interval (CI).

$\mathrm{IBD}$, inflammatory bowel disease

\section{Infant and child diet}

Children with UC received sucrose supplemented milk more often than controls (OR $2.25(1-5.2) ; p=0.05)$. There was no significant difference in the age of introduction of flour, meat, and vegetables. As in $C D$, there was no difference for passive smoking between UC and controls.

\section{Childhood diseases, vaccinations}

Appendicectomy was a strong protective factor for UC with an OR of $0.3(0.1-0.95 ; p=0.03)$. There were no significant differences between cases and controls regarding childhood infectious diseases, including mumps, measles, and rubella. UC cases were more often vaccinated against smallpox and poliomyelitis with no differences for other vaccinations, including MMR, BCG, and hepatitis B.

\section{Home amenities}

All but three children had permanent access to separate bathroom and fixed hot water. In UC, there was no difference in water consumption or water evacuation. UC children shared their bedroom more often (OR 3.4 (1.5-7.9); $\mathrm{p}=0.002$ ).

\section{Multivariate analysis (table 5)}

When adjusting for mother's educational level, four variables remained significant: family history of IBD, disease during pregnancy, and bedroom sharing, as independent risk factors, and appendicectomy as an independent protective factor.

\section{DISCUSSION}

Our study addressed for the first time in a population based cohort the hypothesis that the development of IBD is associated with early childhood events. Our findings confirm the importance of familial IBD as a risk factor and the strong inverse association between appendicectomy and subsequent UC. It revealed that breast feeding and BCG may be associated with an increased risk of $\mathrm{CD}$. Conversely, no evidence was found for the hygiene hypothesis.

The validity of these findings depends on the reduction of bias and confoundings. We used a population based incident series which was representative of the spectrum of IBD. All children who had a diagnosis of certain or probable CD and UC within the study period were offered a place in the study. No deaths occurred in this population since 1988 and only two patients were lost to follow up. The predominance of CD over UC has been a consistent finding in our area, ${ }^{10}$ explaining the limited number of UC cases recruited. More males with CD and more females with UC (which differs from the distribution observed in adults) has also been a consistent finding in our paediatric population since 1988. We also assume that controls were representative of the general population as they were randomly selected using telephone number lists. Recall bias was minimised by interviewing both children and mothers at home and by checking answers to questions in the paediatric health booklet which was available for almost all cases and controls.
A positive family history was the strongest risk factor for IBD. Having a first degree relative with IBD represents the single most important factor determining an individual's risk of developing the disease. ${ }^{2}$ Polito et al reported the proportion of patients with relatives affected with IBD according to age at diagnosis in the proband. ${ }^{11}$ Thirty per cent of patients diagnosed under 20 years of age had a positive family history, decreasing to $18 \%$ for those diagnosed between 20 and 39 years of age, and to $13 \%$ among those diagnosed after 40 years.

Gilat et al noted a lower than expected rate of appendicectomy in patients diagnosed with UC in childhood. ${ }^{12}$ Thirteen published case control studies were summarised by Koutroubakis et $a l^{13}$ concluding that appendicectomy reduced the risk of UC by $69 \%(62-75 \%)$. The inverse relation between UC and appendicectomy was particularly strong in our paediatric population with an OR of 0.06. Other studies have noted that this relation was stronger with appendicectomy performed before the age of 20 years. ${ }^{14}{ }^{15}$ Several studies found an increased frequency of appendicectomy in CD patients. ${ }^{16}{ }^{17}$ Abdominal pain caused by incipient CD at the time of appendicectomy has been thought to explain this association. ${ }^{18}$ This was confirmed in our series in which 9/13 appendectomies performed within one year before the onset of symptoms were actually undetected CD at the time of operation. In a large cohort study, the risk of CD associated with appendicectomy remained when the follow up started 10 years after appendicectomy, arguing against this hypothesis. ${ }^{19}$ Nevertheless, patients operated on before the age of 10 years had a low risk, suggesting an age dependent difference in the pathogenesis of appendicitis. ${ }^{19}$

We explored various factors relevant to the infectious hypothesis in IBD and conversely the hygiene hypothesis. Lack of infections in early childhood could increase the risk of IBD later in life. Studies by Gent and colleagues ${ }^{20}$ and Duggan and colleagues ${ }^{14}$ showing that $\mathrm{CD}$ was more common in children who had access to a hot water supply and a separate bathroom supported this hypothesis. We could not confirm this finding as almost all cases and controls had access to these facilities. Earlier work by Gilat and colleagues ${ }^{12}$ was also unable to support this hypothesis. Bedroom sharing was a risk factor for both $\mathrm{CD}$ and UC in univariate analysis and for UC in multivariate analysis (adjusted on educational level and family size). This may be a surrogate marker of exposure to infections early in life because the more crowded the living conditions, the more frequent is exposure to infections. Children with IBD also had more older siblings than controls. In recent studies, it was shown that the number of older siblings conferred an incremental increased risk of developing $\mathrm{UC}^{21}$ and that lower birth rank, as a possible indicator of increased childhood infection exposure, was associated with a higher risk of IBD. ${ }^{22}$ These findings are consistent with the observation that older siblings increase the risk and severity of secondary infections in younger siblings. The role of infections early in life has been the focus of many investigations. Increased frequency of gastroenteritis, ${ }^{23}$ and respiratory $^{12}$ and perinatal ${ }^{24}$ infections in IBD has been reported. A history of frequent childhood infections or exposure to antibiotics has also been proposed as a risk factor for IBD. ${ }^{25}$ Our study thus adds to the notion that indicators of childhood infection exposure are associated with an increased risk of IBD. On the other hand, drinking tap water made a significant contribution to the multivariate model in CD. Source of drinking water has not previously been recognised as a risk or protective factor in IBD. One explanation could be the presence in tap water of harmless environmental species (as opposed to infectious organisms) which may have a particular ability to trigger regulatory $\mathrm{T}$ cells. ${ }^{26}$

An increased risk of IBD among persons born during a measles epidemic ${ }^{27}$ as well as a close temporal relationship 
between measles infection and the development of IBD has been suggested. ${ }^{28}$ Live attenuated measles vaccination has also been implicated. ${ }^{29}$ Furthermore, a high risk of CD in patients whose mothers were infected with measles around the time of birth has been reported. ${ }^{30}$ We could not confirm these findings. There was no difference between cases and controls regarding exposure to measles as the wild or attenuated virus. None of the mothers reported measles during pregnancy. MMR vaccination was negatively associated with a risk of $\mathrm{CD}$, confirming data from four large health maintenance organisations in the USA. ${ }^{31}$ In contrast, smallpox and poliomyelitis vaccination were associated with an increased risk of both CD and UC.

The association between BCG and an increased risk of CD was particularly convincing because it was dose dependent and remained in the multivariate analysis. BCG is associated with a Thl immune response. ${ }^{32}$ It has been proposed that administration of BCG early in life could protect against the development of allergic disorders with a predominant Th2 response. ${ }^{33}$ It is generally accepted that CD is a disorder with a predominant Thl immune response. ${ }^{1}$ Modulation of the immature immune system early in life towards a Thl immune response could thus favour the development of CD.

The results of this study were essentially negative with regard to dietary factors. Sucrose supplemented milk was associated with an increased risk of UC, thus confirming a consistent positive association in the literature. ${ }^{34-39}$ However, in most studies, high sugar intake could have reflected a shift to a more palatable diet as a consequence of the illness.

Adult cigarette smoking is associated with the development of CD and protection from the development of UC. Studies on exposure to passive smoking in childhood have provided controversial results: association with an increased risk of both $\mathrm{CD}$ and $\mathrm{UC}^{40}$ lower incidence of $\mathrm{UC}^{41}$ not confirmed in another study. ${ }^{42}$ Our results do not support a role for passive smoking on the occurrence of either UC or CD among children and adolescents.

Several studies have suggested a protective effect of breast feeding against the subsequent development of IBD. ${ }^{33}$ Certainly, the unexpected finding of our study was that breast feeding was associated with an increased risk of CD. Breast feeding is known to provide immunological protection to the newborn. Delayed infections occurring at weaning may lead to an inappropriate immune response and persistence of intestinal inflammation. Another hypothesis may be related to breast milk pollution in our highly industrialised area. Drugs, industrial chemicals, and environmental contaminants can be present in breast milk. ${ }^{44}$ Ultrafine and fine particles are potent adjuvants in antigen mediated immune response and cause inflammation in susceptible individuals; a relationship between microparticles and CD has recently been considered. ${ }^{45-48}$

Finally, we have confirmed previous reports of an association between CD and childhood eczema ${ }^{12}{ }^{49}$ and between UC and disease during pregnancy. ${ }^{24}$ Non-infectious events in the mother before delivery, including pre-eclampsia and threatened delivery, increased by 3.6-fold (2.1-6.2) the risk of IBD in children. ${ }^{24}$ The explanation for these apparent links is unclear.

In conclusion, this study confirms the strong risk of IBD associated with familial disease and the protective effect for later occurrence of UC of appendicectomy in childhood. It provides some important negative findings regarding the role of hygiene, some viral infections, and dietary factors. It shows for the first time an association between IBD and environmental factors such as drinking water, BCG, and breast feeding. Epidemiology of IBD in our region is unique and characterised by a much higher incidence of CD than
$\mathrm{UC}^{9}{ }^{10}$ a still increasing incidence of $\mathrm{CD}$ and a decreasing incidence of $\mathrm{UC}^{10}$ and the presence of unusual familial aggregations..$^{50-53}$ It is thus worth stressing that studies in other populations are needed to confirm or refute these results. Meanwhile, no practical conclusions should be drawn. In particular, extensive biological and epidemiological research has documented compelling benefits for breast fed infants. Breast feeding should not in any case be discouraged in young infants at the present time. In a public health perspective, the short and long term benefits of breast feeding overrule by far the increased risk of CD that was observed in the present study.

\section{ACKNOWLEDGEMENTS}

We thank all of the children and their mothers who participated in the study. The authors thank the interviewer practitioners who collected the data: B Lemaire, N Guillon, M Inglard, I Rousseau, $\mathrm{N}$ Wauquier, $\mathrm{P}$ Fosse, $\mathrm{M}$ Lecomte, $\mathrm{D}$ Panis, L Yzet, C Dias, M. Boddaert, M Malo, M Dard, and S Richon. EPIMAD is organised under an agreement between the Institut National de la Santé et de la Recherche Médicale (INSERM), the Direction Générale de la Santé (DGS), and the Institut National de Veille Sanitaire (InVS), and is also supported by the François Aupetit Association, the Ferring Laboratories, IRMAD (Astra Company), the Observatoire Régional de la Santé du Nord-Pas-de-Calais, the Caisse Régionale d'Assurance Maladie de Nord Picardie, and the $\mathrm{CH}$ et $\mathrm{U}$ and Faculte de Medecine de Lille.

We thank all of the gastroenterologists and specialists who participated in this study: André JM, Antonietti $M$, Armand A, Aroichane I, Aubet JP, Auxenfants E, Barbry B, Bardoux N, Baron P, Baudet A, Bazin B, Bebahani A, Becqwort JP, Benet V, Benguigui C, Ben Soussan E, Bental A, Berkelmans I, Bernet J, Bernou-Dron C, Bertot $\mathrm{P}$, Biron N, Bleuet $\mathrm{M}$, Blondel $\mathrm{F}$, Bohon $\mathrm{F}$, Boniface $\mathrm{E}$, Bonnière $\mathrm{P}$, Bonvarlet $\mathrm{E}$, Bonvarlet $\mathrm{P}$, Boruchowicz $\mathrm{A}$, Bostvironnois R, Bouche B, Boudaillez C, Bourgeaux C, Bourguet A, Bourienne A, Bray G, Brazier F, Breban P, Brung-Lefebvre V, Burgiere P, Butel J, Canva JY, Canva-Delcambre V, Capron JP, Cardot F, Carpentier P, Cartier E, Cassar JF, Castex JF, Catteau L, Caujolle B, Cayron G, Chantre M, Charles J, Charneau T, Claerbout JF, Clergue PY, Cohen G, Collet R, Crinquette JF, Dadamessi I, Dapvril V, Davion T, Debas J, Dehont F, Delatre C, Delcenserie R, Delette O, Delgrange $T$, Delhoustal L, Delmotte JS, Deregnaucourt G, Descombes P, Desechalliers JP, Desmet P, Desseaux G, Desurmont P, Devienne A, Devred M, Devroux A, Dewailly A, Dubois R, Ducatillon P, Duclay J, Ducrocq B, Ducrot F, Ducrotte P, Dufilho J, Duhamel C, Dujardin D, Dupont F, Duranton Y, Elie-Legrend MC, Evrard JP, Filoche B, Finet L, Foissey D, Foutrein-Comes MC, Foutrein P, Frere T, Gallet P, Gamblin C, Geslin G, Gheyssens Y, Gilbert T, Godard P, Godchaux JM, Godchaux R, Goria O, Gottrand F, Gower P, Grandmaison B, Guedon C, Guillard JF, Guillem L, Guillemot F, Hanon D, Heckestweiller P, Hedde JP, Hellal H, Heyman B, Heraud M, Herve S, Hochain P, Houcke P, Ivanovic A, Janicki E, Jeu J, Jonas C, Kerleveo A, Kiriakos A, Kiriakos J, Klein O, Kornhauser R, Koutsomanis D, Laberenne JE, Laffineur G, Lannoy P, Lapchin J, Laprand M, Laude D, Lecieux P, Leclerc N, Le Couteulx C, Ledent J, Lefebvre J, Le Grix A, Lelong P, Lenaerts C, Leplat A, Leroi H, Leroy MY, Lesage JP, Lesage X, Lesage J, Lescanne-Darchis I, Lescut J, Lescut D, Leurent B, Lhermie M, Lion A, Lisambert B, Loire F, Luciani M, Lucidarme D, Lugand J, Macaigne O, Maetz D, Maillard D, Mancheron H, Marti R, Martin F, Martin G, Marzloff E, MathieuChandelier C, Mauillon J, Maunoury V, Maupas JL, Mesnard B, Metayer P, Meurisse B, Meurisse F, Mirmaran X, Modaine T, Morel L, Moulin E, Mouterde O, Mudry J, N'GuyenTack R, Notteghem B, Ostyn A, Ouvry D, Panien-Claudot N, Paoletti C, Papazian A, Parent B, Paris JC, Patrier P, Paupart L, Pauwels B, Pauwels M, Petit R, Piat M, Piotte S, Plane C, Plouvier B, Pollet E, Pommelet P, Pouchain G, Prades P, Prevost A, Prevost JC, Queuniet AM, Quinton JF, Rabache A, Rabelle P, Razemon V, Reix N, Richez C, Robinson P, Rodriguez J, Roger J, Roux JM, Rudelli A, Savoye G, Schlosseberg P, Segrestin M, Seryer A, Sevenet F, Silvie J, Simon V, Spyckerelle C, Talbodec N, Thelu JL, Thorel JM, Toisin J, Tonnel J, Touchais JY, Tranvouez JL, Triplet C, Turck D, Vaillant E, Valmage C, Vanco D, Vanderbecq E, Vandermolen $\mathrm{P}$, Vandevenne $\mathrm{P}$, Vandewalle $\mathrm{C}$, Vanhoove JP, Verbiese G, Vermelle P, Verne C, Vincendet M, Viot J, Voiment YM, Waeghemaecker L, Wallez JY, Wantiez M, Weber J, Willocquet JL, Wolschies E, Zellweger A, Ziade C. 


\section{Authors' affiliations}

S Baron, C Leplat, C Gower-Rousseau, R Marti, S Debeugny, J-L

Salomez, Registre des Maladies Inflammatoires Chroniques de l'Intestin (EPIMAD), Service d'Epidémiologie et de Santé Publique, Hôpital Calmette, Lille, France

D Turck, EPIMAD, Clinique de Pédiatrie, Hôpital Jeanne de Falndre, Lille, France

V Merle, E Lerebours, EPIMAD, Centre de Rouen, Hôpital Charles Nicolle, Rouen, France

T Yzet, J-L Dupas, EPIMAD, Centre d' Amiens, Hôpital Nord, Amiens, France

A Cortot, J-F Colombel, EPIMAD, Service d'Hépato-Gastroentérologie, Hôpital Huriez, Lille, France

Conflict of interest: None declared.

\section{REFERENCES}

1 Podolsky DK. Inflammatory bowel disease. N Engl J Med 2002;347:417-29.

2 Ahmad T, Tamboli CP, Jewell DP, et al. Clinical relevance of advances in genetics and pharmacogenetics of IBD. Gastroenterology 2004; 126:1533-49.

3 Loffus EV Jr. Clinical epidemiology of inflammatory bowel disease: Incidence, prevalence, and environmental influences. Gastroenterology 2004; 126:1504-17.

4 Marshall JK, Hilsden RJ. Environment and epidemiology of inflammatory bowel diseases. In: Satsangi J, Sutherland RL, eds. Inflammatory bowel diseases. London: Churchill Livingston, 2003:17-28.

5 Montgomery SM, Pounder RE, Wakefield AJ. Infant mortality and the incidence of inflammatory bowel disease. Lancet 1997;349:472-3.

6 Shivananda S, Lennard-Jones J, Logan R, et al. Incidence of inflammatory bowel disease across Europe: is there a difference between north and south? Results of the European Collaborative Study on Inflammatory Bowel Disease (EC-IBD). Gut 1996;39:690-7.

7 Ekbom A. The epidemiology of IBD: a lot of data but little knowledge. How shall we proceed? Inflamm Bowel Dis 2004:10:S32-4.

8 Bach JF. The effect of infections on susceptibility to autoimmune and allergic diseases. N Engl J Med 2002;347:91 1-20.

9 Gower-Rousseau C, Salomez JL, Dupas JL, et al. Incidence of inflammatory bowel disease in northern France (1988-1990). Gut 1994;35:1433-8.

10 Molinie F, Gower-Rousseau C, Yzet T, et al. Opposite evolution in incidence of Crohn's disease and ulcerative colitis in Northern France (1988-1999). Gut 2004; $53: 843-8$.

11 Polito JM 2nd, Childs B, Mellits ED, et al. Crohn's disease: influence of age at diagnosis on site and clinical type of disease. Gastroenterology 1996:111:580-6.

12 Gilat T, Hacohen D, Lilos P, et al. Childhood factors in ulcerative colitis and Crohn's disease. An international cooperative study. Scand I Gastroenterol 1987;22:1009-24.

13 Koutroubakis IE, Vlachonikolis IG, Kouroumalis EA. Role of appendicitis and appendectomy in the pathogenesis of ulcerative colitis: a critical review. Inflamm Bowel Dis 2002;8:277-86.

14 Duggan AE, Usmani I, Neal KR, et al. Appendicectomy, childhood hygiene, Helicobacter pylori status, and risk of inflammatory bowel disease: a case control study. Gut 1998:43:494-8.

15 Andersson RE, Olaison G, Tysk C, et al. Appendectomy and protection against ulcerative colitis. N Engl I Med 2001;344:808-14.

16 Russel MG, Dorant E, Brummer RJ, et al. Appendectomy and the risk of developing ulcerative colitis or Crohn's disease: results of a large case-control study. South Limburg Inflammatory Bowel Disease Study Group. Gastroenterology 1997;113:377-82.

17 Koutroubakis IE, Vlachonikolis IG, Kapsoritakis A, et al. Appendectomy, tonsillectomy, and risk of inflammatory bowel disease: case-controlled study in Crete. Dis Colon Rectum 1999:42:225-30

18 Frisch M, Johansen C, Mellemkjaer L, et al. Appendectomy and subsequent risk of inflammatory bowel diseases. Surgery 2001;130:36-43.

19 Andersson RE, Olaison G, Tysk C, et al. Appendectomy is followed by increased risk of Crohn's disease. Gastroenterology 2003;124:40-6.

20 Gent AE, Hellier MD, Grace RH, et al. Inflammatory bowel disease and domestic hygiene in infancy. Lancet 1994;343:766-7.

21 Montgomery SM, Lambe M, Wakefield AJ, et al. Siblings and the risk of inflammatory bowel disease. Scand J Gastroenterol 2002;37:1301-8.

22 Hampe J, Heymann K, Krawczak M, et al. Association of inflammatory bowel disease with indicators for childhood antigen and infection exposure. Int J Colorectal Dis 2003;18:413-17.
23 Whorwell PJ, Holdstock G, Whorwell GM, et al. Bottle feeding, early gastroenteritis, and inflammatory bowel disease. Br Med J 1979;1:382

24 Ekbom A, Adami HO, Helmick CG, et al. Perinatal risk factors for inflammatory bowel disease: a case-control study. Am J Epidemiol 1990:132:1111-19.

25 Wurzelmann Jl, Lyles CM, Sandler RS. Childhood infections and the risk of inflammatory bowel disease. Dig Dis Sci 1994;39:555-60.

26 Rook GA, Adams V, Hunt J, et al. Mycobacteria and other environmental organisms as immunomodulators for immunoregulatory disorders. Springer Semin Immunopathol 2004:25:237-55.

27 Ekbom A, Wakefield AJ, Zack $M$, et al. Perinatal measles infection and subsequent Crohn's disease. Lancet 1994;344:508-10.

28 Montgomery SM, Morris DL, Pounder RE, et al. Paramyxovirus infections in childhood and subsequent inflammatory bowel disease. Gastroenterology 1999:116:796-803.

29 Thompson NP, Montgomery SM, Pounder RE, et al. Is measles vaccination a risk factor for inflammatory bowel disease? Lancet 1995;345: 1071-4.

30 Ekbom A, Daszak P, Kraaz W, et al. Crohn's disease after in-utero measles virus exposure. Lancet 1996:348:515-17.

31 Davis RL, Bohlke K. Measles vaccination and inflammatory bowel disease: controversy laid to rest? Drug Safety 2001;24:939-46.

32 Ota MO, Vekemans J, Schlegel-Haueter SE, et al. Influence of Mycobacterium bovis bacillus Calmette-Guerin on antibody and cytokine responses to human neonatal vaccination. J Immunol 2002;168:919-25.

33 Krishna MT, Salvi SS. Could administration of bacille Calmette-Guerin vaccination at birth protect from the development of asthma and allergic diseases in the western world? Has this question been adequately investigated? Pediatr Allergy Immunol 2002;13:172-6.

34 Mayberry JF, Rhodes J, Newcombe RG. Increased sugar consumption in Crohn's disease. Digestion 1980;20:323-6.

35 Jarnerot G, Jarnmark I, Nilsson K. Consumption of refined sugar by patients with Crohn's disease, ulcerative colitis, or irritable bowel syndrome. Scand J Gastroenterol 1983;18:999-1002.

36 Katschinski B, Logan RF, Edmond M, et al. Smoking and sugar intake are separate but interactive risk factors in Crohn's disease. Gut 1988;29:1 202-6.

37 Persson PG, Ahlbom A, Hellers G. Diet and inflammatory bowel disease: case-control study. Epidemiology 1992;3:47-52.

38 Reif S, Klein I, Lubin F, et al. Pre-illness dietary factors in inflammatory bowel disease. Gut 1997:40:754-60.

39 Riordan $\mathbf{A M}$, Ruxton $\mathrm{CH}$, Hunter JO. A review of associations between Crohn's disease and consumption of sugars. Eur I Clin Nutr 1998:52:229-38.

40 Lashner BA, Shaheen NJ, Hanauer SB, et al. Passive smoking is associated with an increased risk of developing inflammatory bowel disease in children. Am J Gastroenterol 1993;88:356-9.

41 Sandler RS, Sandler DP, McDonnell CW, et al. Childhood exposure to environmental tobacco smoke and the risk of ulcerative colitis. Am J Epidemiol 1992;135:603-8.

42 Persson PG, Ahlbom A, Hellers G. Inflammatory bowel disease and tobacco smoke-a case-control study. Gut 1990;31:1377-81

43 Davis MK. Breastfeeding and chronic disease in childhood and adolescence. Pediatr Clin North Am 2001;48:125-41.

44 Pronczuk J, Akre J, Moy G, et al. Global perspectives in breast milk contamination: infectious and toxic hazards. Environ Health Perspect 2002;110:A349-51.

45 Lomer MC, Harvey RS, Evans SM, et al. Efficacy and tolerability of a low microparticle diet in a double blind, randomized, pilot study in Crohn's disease. Eur J Gastroenterol Hepatol 2001;13:101-6.

46 Lomer MC, Thompson RP, Powell JJ. Fine and ultrafine particles of the diet: influence on the mucosal immune response and association with Crohn's disease. Proc Nutr Soc 2002;61:123-30.

47 Powell JJ, Harvey RS, Thompson RP. Microparticles in Crohn's disease-has the dust settled? Gut 1996;39:340-1.

48 Powell JJ, Harvey RS, Ashwood P, et al. Immune potentiation of ultrafine dietary particles in normal subjects and patients with inflammatory bowe disease. J Autoimmun 2000;14:99-105.

49 Feeney MA, Murphy F, Clegg AJ, et al. A case-control study of childhood environmental risk factors for the development of inflammatory bowel disease. Eur J Gastroenterol Hepatol 2002;14:529-34.

50 Van Kruiningen $\mathrm{HJ}$, Colombel JF, Cartun RW, et al. An in-depth study of Crohn's disease in two French families. Gastroenterology 1993;104:351-60.

51 Colombel JF, Grandbastien B, Gower-Rousseau C, et al. Clinical characteristics of Crohn's disease in 72 families. Gastroenterology 1996;111:604-7

52 Van Kruiningen $\mathrm{HJ}$, Cortot A, Colombel JF. The importance of familial clusterings in Crohn's disease. Inflamm Bowel Dis 2001;7:170-3.

53 Laharie D, Debeugny S, Peeters $M$, et al. Inflammatory bowel disease in spouses and their offspring. Gastroenterology 2001;120:816-19.

13-15 April 2005, ExCel Conference Centre, London

For further information on how to register please go to:

http://www.quality.bmipg.com 